\title{
FORMULASI DAN UJI EFEKTIVITAS GEL EKSTRAK BUAH PARE (Momordica charantia L) Terhadap BAKTERI Staphylococcusepidermidis dan Propionibacterium acnes PENYEBAB JERAWAT
}

\author{
Nur Ain Thomas' ${ }^{1}$, Widysusanti Abdulkadir'), Mega Agustiwi Mohi ${ }^{1)}$ \\ 1) Jurusan Farmasi, Fakultas Olahraga dan Kesehatan \\ Universitas Negeri Gorontalo
}

\begin{abstract}
Acne is a skin disease in the form of inflammation in the layer of polysebaseus triggered by the bacteria Staphyloccoccus epidermidis and Propionibacterium acnes. One plant that is empirically and based on scientific data has anti-acne properties is bitter melon (Momordica charantia L). In pare fruit extract contains flavonoids which are thought to be able to act as active compounds in the form of anti-acne. This study aims to formulate bitter melon extract as an anti-acne gel and determine the inhibition of bitter melon extract gel against acne-causing bacteria, namely Staphylococcus epidermidis and Propionibacterium acne. Pare fruit extract gel with 3 variations of extract concentration, namely 5\%, 7.5\% and 10\%. Evaluation of gel preparations included organoleptic test, homogeneity, spreadability, $\mathrm{pH}$, viscosity, and irritation test. Data analysis using Oneway ANOVA. Based on the results of the research conducted, it can be concluded that bitter fruit extract (Momordica charantia L) can be formulated as an anti-acne gel, and the preparation of bitter fruit extract gel (Momordica charantia L) at a concentration of $10 \%$ has a inhibition of $10 \mathrm{~mm}$ against Staphylococcus epidermidis and 7, $1 \mathrm{~mm}$ against the bacterium Propionibacterium acne which is included in the medium category.
\end{abstract}

Keywords: Acne, Extract, Gel, Stahpylococcus epidermidis, Propionibacterium acnes

\begin{abstract}
ABSTRAK
Jerawat merupakan penyakit kulit berupa peradangan pada lapisan polisebaseus yang dipicu oleh bakteri Staphyloccoccus epidermidis dan Propionibacterium acnes. Salah satu tanaman yang secara empiris dan berdasarkan data ilmiah memiliki khasiat antijerawat adalah buah pare (Momordica charantia L). Dalam ekstrak buah pare terkandung flavonoid yang diduga dapat berperan sebagai senyawa aktif sedian antijerawat. Penelitian ini bertujuan untuk memformulasikan ekstrak buah pare sebagai gel antijerawat dan menentukan daya hambat gel ekstrak buah pare terhadap bakteri penyebab jerawat yaitu Staphylococcus epidermidis dan Propionibacterium acne. Gel ekstrak buah pare dengan 3 variasi konsentrasi ekstrak yaitu 5\%, 7,5\% dan 10\%. Evaluasi sediaan gel meliputi uji organoleptik, homogenitas, daya sebar, $\mathrm{pH}$, viskositas, dan uji iritasi.Analisis data menggunakan ANOVA Oneway. Berdasarkan hasil penelitian yang dilakukan maka dapat disimpulkan bahwa ekstrak buah pare (Momordica charantia L) dapat diformulasikan sebagai gel antijerawat, dan sediaan gel ekstrak buah pare (Momordica charantia L) pada konsentrasi $10 \%$ mempunyai daya hambat $10 \mathrm{~mm}$ terhadap bakteri Staphylococcus epidermidis dan 7,1 mm terhadap bakteri Propionibacterium acne yang termasuk dalam kategori sedang.
\end{abstract}

Kata Kunci :Jerawat, Ekstrak Buah Pare, Gel, Stahpylococcus epidermidis, Propionibacterium acnes 


\section{PENDAHULUAN}

Penyakit kulit yang paling sering diderita oleh masyarakat adalah jerawat.Jerawat dapat terjadi disebabkan karena kulit berminyak. Kulit berminyak banyak dialami oleh orang yang berada didaerah tropis, disebabkan pengaruh sinar matahari yang terlalu panas sehingga kelenjar minyak (sebaceous gland) sangat produktif dan tidak mampu mengontrol jumlah minyak (sebum) yang harus dikeluarkan (Djajadisastra, 2009). Selain itu, juga disebabkan oleh debu dan kotoran yang berasal dari luar menempel pada kulit berminyak, kemudian masuk kedalam pori-pori kulit. Kotoran tersebut menumpuk bersama sel-sel kulit mati yang jelas dibiarkan akan menjadi media yang baik bagi pertumbuhan bakteri dan pada akhirnya dapat menyebabkan jerawat. Jerawat ini dapat menyebabkan rasa gatal yang mengganggu bahkan rasa sakit.Umumnya tidak ada efek menyeluruh pada tubuh yang ditimbulkan. Walaupun tampak ringan, masalah jerawat pada kulit bisa bertambah parah jika tidak segera ditangani, akan terjadi peradangan hebat (Mertaniasih, 1996).

Jerawat atau acne vulgaris adalah kelainan berupa peradangan pada lapisan polisebaseus yang disertai penyumbatan dan penimbunan bahan keratin yang dipicu oleh bakteri (Wasitaatmadja, 1997). Mikroorganisme seperti Staphylococcus epidermidis dan Propionibacterium acnesikut berperan dalam pathogenesis penyakit ini dengan cara memproduksi metabolit yang dapat bereaksi dengan sebum sehingga meningkatkan proses inflamasi.

Bakteri Staphylococcus epidermidis dan Propionibacterium acnes merupakan bakteri gram positif.Alasan digunakan kedua bakteri ini karena ditinjau dari segi bentuk dan tempat hidupnya.Dimana bakteri Staphylococcus epidermidis memiliki bentuk kokus, dan tempat hidupnya sebagian besar dilingkungan luar. Berbeda dengan bakteri Propionibacterium acnes, merupakan bakteri dengan bentuk basil, yang merupakan mikrobiota kulit atau dikenal dengan floral normal kulit yang ditemukan pada kulit yang kaya akan kelenjar sebasea.

Salah satu tanaman yang secara empiris dan berdasarkan data ilmiah memiliki khasiat antijerawat adalah buah pare (Momordica charantia L). Tanaman ini dapat tumbuh liar atau dibudidayakan sehingga masyarakat dapat mengkonsumsi buah pare. Senyawa yang terdapat dalam daging buah pare meliputi alkaloid, flavonoid, saponin, polifenol dan steroid, namun senyawa yang berperan sebagai antibakteri adalah flavonoid, alkaloid dan saponin (Laianto, 2014). 
Salah satu upaya untuk mengembangkan tanaman obat agar menjadi sediaan yang lebih modern adalah membuatnya dalam bentuk sediaan gel. Gel merupakan suatu sediaan setengah padat yang terdiri dari partikel anorganik kecil/organik besar terpenetrasi oleh suatu cairan, berupa masa transparan atau buram yang digunakan untuk sediaan topikal. Keuntungan dari gel yaitu memberikan efek pendinginan pada kulit.Bentuk sediaan gel lebih baik digunakan pada pengobatan jerawat dibanding bentuk sediaan krim karena sediaan gel dengan pelarut yang polar lebih mudah dibersihkan dari permukaan kulit setelah pemakaian dan tidak mengandung minyak yang dapat meningkatkan keparahan jerawat (Sasanti, 2012).

Maka untuk mengetahui manfaat buah pare sebagai antibakteri, dilakukan penelitian ini yaitu membuat suatu formulasi gel anti jerawat dari ekstrak buah pare (Momordica charantia L) dan dilakukan pengujian aktivitas antibakteri terhadap bakteri Staphylococcus epidermidis dan Propionibacterium acnes.

\section{METODE PENELITIAN}

\section{Bahan}

Ekstrak buah pare (Momordica charantia L), bakteri Propionibacterium acnes, etanol 96\%, media agar darah, mediaNA, bakteri Staphylococcus epidermidis, kertas cakram uji, aqua destilata,HPMC, Propilenglikol, Gliserin, Aquadest, DMDM hydantoin, asam fosfat, natrium fosfat, Alkohol 70\%, kertas perkamen, $\mathrm{HCl}$, pereaksi mayer, pereaksi bouchardat, amil alkohol,aluminum foil, wadah gel, penggaris, tissue.

Alat

gelas kimia, inkubator, neraca analitik, tabung reaksi, cawan petri, oven, penangas air, gelas ukur, batang pengaduk, sudip, sendok tanduk, cawan porselin, autoklaf, kertas saring, rak tabung, lampu spritus, jarum ose, lumpang, alu, kaca arloji, pipet tetes,thermometer.

\section{Pembuatan Simplisia Buah Pare}

Buah pare dikumpulkan dan dibersihkan dari kotoran-kotoran yang menempel (sortasi basah), dicuci dengan air mengalir sampai bersih, kemudian ditiriskan. Buah yang telah bersih yang telah bersih dari air cucian kemudian dipisahkan dari bijinya lalu dirajang tipis tipis dengan ketebalan kurang lebih 0,1 $\mathrm{cm}$, kemudian diangin-anginkan pada tempat yang tidak dibawah sinar matahari langsung hingga terbentuk simplisia kering.Selanjutnya simplisia kering dibersihkan kembali dari kotoran yang mungkin tidak hilang saat pencucian (sortasi kering). Selanjutnya disimpan dalam wadah bersih dan tertutup. 
Pembuatan Ekstrak Buah Pare (Momordica charantia L)

Prosedur kerja proses ekstraksi pada penelitian ini dilakukan dengan menggunakan metode maserasi.

Maserasi dilakukan dengan cara merendam simplisia buah pare menggunakan pelarut etanol $96 \%$ selama 5 hari dan dilakukan pengadukan setiap 1-2 jamhingga diperoleh ekstrak cair hasil maserasi selama 5 hari. Hasil maserasi tersebut kemudian disaring menggunakan kertas saring dan dikumpulkan untuk dievaporasi menggunakan vacuum rotary evaporatorhingga diperoleh maserat murni tanpa ada campuran pelarut. Selanjutnya diuapkan kembali diatas hotplate pada suhu $75^{\circ} \mathrm{C}$. Setelah diperoleh ekstrak kental kemudian dimasukkan kedalam vial dan ditimbang.

Skrining Fitokimia Ekstrak Buah Pare (Momordica charantia L).

\section{Uji Alkaloid}

Sejumlah ekstrak kental dimasukkan kedalam tabung reaksi dan ditambahkan methanol sebanyak $5 \mathrm{ml}$ dan amoniak sebanyak $5 \mathrm{ml}$. kemudian dipanaskan beberapa menit, lalu dibagi kedalam 2 tabung reaksi. Untuk tabung 1 ditetesi dengan pereaksi mayer dan tabung 2 ditetesi pereaksi dragendrof. Apabila tabung 1 menghasilkan endapan putih maka positif mengandung senyawa alkaloid.Apabila tabung 2 mengahasilkan perubahan warna menjadi kuning atau merah bata maka postif mengandung senyawa alkaloid

\section{Uji Flavonoid}

Sejumlah ekstrak dimasukkan kedalam tabung reaksi, kemudian ditambahakan etanol secukupnya.Ditetesi dengan $\mathrm{HCl}$ sebanyak 5 tetes dan ditambahkan Serbuk $\quad \mathrm{Mg}$ secukupnya.Selanjutnya divortex, dan apabila terdapat perubahan warna menjadi merah, kuning, atau jingga maka positif mengandung senyawa flavonoid.

\section{Uji Saponin}

Sejumlah ekstrak dimasukkan ke dalam tabung reaksi, kemudian ditambahkan etanol secukupnya.Ditambahkan aquadest yang telah dipanaskan sebelumnya, lalu dikocok dengan kuat.Apabila terdapat buih, maka positif mengandung senyawa saponin.

\section{Optimasi Basis}

Tabel 1.Optimasi Basis Gel

\begin{tabular}{|c|c|c|c|}
\hline \multirow{2}{*}{ Bahan } & \multicolumn{3}{|c|}{ Konsentrasi (\%) } \\
\cline { 2 - 4 } & $\mathbf{F}_{\mathbf{1}}$ & $\mathbf{F}_{\mathbf{2}}$ & $\mathbf{F}_{\mathbf{3}}$ \\
\hline HPMC & 1 & 1,5 & 2 \\
\hline Aquadest & 100 & 100 & 100 \\
\hline \multirow{3}{*}{ Hasil } & Jernih & Jernih & Jerni \\
& , cair, &, & $\mathrm{h}$, \\
& viskos & viskos & visk \\
& rendas & itas & osita \\
& renda & s \\
& h & baik \\
\hline
\end{tabular}


Optimasi basis dilakukan untuk mengetahui konsentrasi basis atau gelling agent yang tepat yang digunakan dalam formula untuk menghasilkan gel yang sesuai dengan persyaratan.Langkah awal yang dilakukan yaitu ditimbang masingmasing HPMC dan aquadest.Kemudian aquadest dipanaskan diatas hot plate pada suhu $80^{\circ} \mathrm{C}$, kemudian ditaburkan HPMC diatasnya hingga mengembang, lalu ditutup dengan aluminium foil, dan didiamkan selama kurang lebih 15 menit.Langkah selanjutnya yaitu di stirrerdengan kecepatan kurang dari 100 rpm.Prosedur yang sama dilakukan pada konsentrasi $1,5 \%$ dan $2 \%$.

\section{Pembuatan Gel Ekstrak Buah Pare}

Pada penelitian ini akan dibuat sediaan gel dengan variasi konsentrasi ekstrak yang berbeda yaitu konsentrasi 5\%, dan 7,5\%, $10 \%$. Formulasi gel yang akan dibuat adalah 50 gram dengan konsentrasi yaitu sebagai berikut:
Tabel 2. Formulasi Gel Ekstrak Buah

Pare (Momordica charantia L.)

\begin{tabular}{|c|c|c|c|}
\hline \multirow{2}{*}{ Komponen } & \multicolumn{3}{|c|}{ Konsentrasi (\%) } \\
\cline { 2 - 4 } & $\mathbf{F 3}_{\mathbf{A}}$ & $\mathbf{F 3}_{\mathbf{B}}$ & $\mathbf{F 3}_{\mathbf{C}}$ \\
\hline $\begin{array}{c}\text { Ekstrak buah } \\
\text { pare }\end{array}$ & 5 & 7,5 & 10 \\
\hline HPMC & 2 & 2 & 2 \\
\hline Gliserin & 10 & 10 & 10 \\
\hline $\begin{array}{c}\text { Propilengliko } \\
1\end{array}$ & 5 & 5 & 5 \\
\hline $\begin{array}{c}\text { Dmdm } \\
\text { Hydantoin }\end{array}$ & 1 & 1 & 1 \\
\hline Asam Fosfat & 0,843 & 0,84 & 0,843 \\
\hline Natrium & 0,082 & 0,08 & 0,082 \\
fosfat & 7 & 27 & 7 \\
\hline Aquadest & 100 & 100 & 100 \\
\hline
\end{tabular}

Cara Pembuatan yaitu :Disiapkan semua bahan yang akan digunakan. Bahan ditimbang sesuai dengan formula yang ada.HPMC didispersikan kedalam air suling yang telah dipanaskan dengan suhu $80^{\circ} \mathrm{C}$, kemudian didiamkan selama 15 menit.Selanjutnya di aduk menggunakan stirrer dengan kecepatan kurang dari 100rpm hingga terbentuk gel.Bahan tambahan seperti propilenglikol, gliserin, dmdm hydantoin, asam fosfat, natrium fosfat, dicampurkankedalam basis gel yang telah terbentuk kemudian distirer. Selanjutnya dilarutkan ekstrak etanol buah pare 5\% dengan sedikit air formula, 
kemudian dicampurkankedalam basis gel yang sudah terbentuk kemudian distirer. Prosedur yang sama juga dilakukan pada ekstrak dengan konsentrasi 7,5\% dan10\%. Gel yang telah terbentuk kemudian disimpan pada suhu ruangan (Hamzah, 2006). Pada pembuatan gel ini juga ditambahkan Gliserin dan propilenglikol bekerja sebagai humektan atau penahan lembab yangberfungsi meningkatkan kelembutan dan daya sebar sediaan juga melindungi dari kemungkinan menjadi kering (Appono, 2014).

\section{Evaluasi Sediaan Gel}

Evaluasi formula meliputi pengujian organoleptik, uji homogenitas, uji daya sebar, kestabilan $\mathrm{pH}$, viskositas dan uji iritasi dari sediaan gel. Sedangkan evaluasi mikrobologi meliputi penentuan efektivitas antibakteri sediaan gel ekstrak buah pare terhadap bakteri S.epidermidis dan P.acnes.

\section{1). Organoleptik}

Pengamatan dilihat secara langsung gel ekstrak buah pare dari segibentuk, warna, dan bau dari gel yang dibuat. Gel biasanya jernih dengan konsistenssetengah padat (Ansel, 1989).

\section{2). Homogenitas}

Pengujian homogenitas dilakukan dengan cara sampel gel dioleskan pada sekeping kaca atau bahan transparan lain yang cocok, sediaan harus menunjukkan susunan yang homogen dan tidak terlihat adanya butiran kasar (Dirjen POM, 1985).

\section{3). Daya Sebar}

Sampel gel diletakkan di atas kaca bulat berdiameter $15 \mathrm{~cm}$, kaca lainnya diletakkan di atasnya dan dibiarkan selama 1 menit.Diameter sebar gel diukur.Setelahnya, ditambahkan 150 gram beban tambahan dan didiamkan selama 1 menit laludiukur diameter yang konstan (Astuti et al., 2010).Daya sebar 5 - $7 \mathrm{~cm}$ menunjukkan konsistensi semisolid yang sangat nyaman dalam penggunaan (Garg et al, 2002).

\section{4). $\mathbf{p H}$}

Penentuan $\mathrm{pH}$ sediaan dilakukan dengan menggunakan $\mathrm{pH}$ meter (soil tester) yang dicelupkan ke dalam sampel gel.Kemudian dilihat angka yang terbaca dan dicocokkan dengan standar $\mathrm{pH} . \mathrm{pH}$ sediaan gel harus sesuai dengan $\mathrm{pH}$ kulit yaitu 4,5-6,5 (Tranggono, 2007).

\section{5). Viskositas}

Pengukuran viskositas dilakukan dengan menempatkan sampel dalam viscometer Brookfield DV-E hingga spindle terendam. Diatur spindle dan kecepatan yangakan digunakan. Viscometer Brookfield DV-E dijalankan, kemudian viskositas dari gel akan terbaca (Septiani, 2011).

\section{6). Uji Iritasi}

Uji iritasi kulit dilakukan langsung pada manusia dengan cara uji tempel 
tertutup (pacth test) pada kulit manusia, dimana sediaan gel lebih kurang 0,1 gram dioleskan pada lengan bagian dalam dengan diameter $2 \mathrm{~cm}$, kemudian ditutup dengan kain kasa steril. Setelah 24 jam, dilakukan pengamatan terhadap gejala yang ditimbulkan setelah penggunaan seperti kemerahan (eritema), gatal-gatal, ataupun bengkak (edema).

\section{Uji Antibakteri Sediaan Gel Ekstrak}

\section{Buah Pare}

Uji mikrobiologi untuk mengetahui efektivitas antibakteri sediaan gel ekstrak buah pare diujikanpada bakteri penyebab jerawat yaitu Propionibacterium acnedan Staphylococcus epidermidis.

\section{Bakteri Staphylococcus epidermidis}

Sebanyak $15 \mathrm{ml}$ media NA dituang kedalam cawan petri.Pada media yang telah padat, biakan bakteri S.epidermidis ditanam menggunakan jarum ose dan digoreskan ke media NA. Kemudian dicelupkan kertas cakram dengan diameter $6 \mathrm{~mm}$ pada gel ekstrak buah pare masingmasing konsentrasi. Diletakkan kertas cakram tersebut pada media yang telah tertanam bakteri.Kemudian diinkubasi dalam inkubator selama 24-48 jam, selanjutnya diukur daerah hambat (zona jernih) pertumbuhan disekitar cakram menggunakan penggaris.Hal ini dilakukan secara triplo atau tiga kali pengulangan.

\section{Bakteri Propionibacterium acnes}

Sebanyak $12 \mathrm{ml}$ media agar darah dituangkan kedalam cawan petri steril.Pada media yang telah padat, biakan bakteri P.acne ditanam dengan menggunakan jarum ose dan digoreskan ke media agar darah. Kemudian dicelupkan kertas cakram dengan diameter $6 \mathrm{~mm}$ pada gel ekstrak buah pare dengan masingmasing konesentrasi. Selanjutnya kertas cakram diletakkan diatas media yang telah tertanam bakteri, kemudian diinkubasi dalam inkubator selama $24-48$ jam, setelah itu diukur diameter daerah hambatan (zona jernih) pertumbuhan disekitar cakram menggunakan penggaris.Hal ini dilakukan secara triplo atau tiga kali pengulangan.

\section{Analisis Data}

Analisis data statistik dilakukan dengan menggunakan uji ANOVA satu arah untuk melihat perbedaan nilai diameter daya hambat sediaan gel ekstrak buah pare dan kontrol positif yang digunakan. 
HASIL PENELITIAN

Tabel 3. Hasil Ekstrak

\begin{tabular}{|c|c|c|}
\hline $\begin{array}{c}\text { Berat } \\
\text { Sampel } \\
(\mathbf{g})\end{array}$ & $\begin{array}{c}\text { Pelarut } \\
\text { etanol } \\
\mathbf{9 6 \%}(\mathbf{m L})\end{array}$ & $\begin{array}{c}\text { Berat } \\
\text { ekstrak } \\
(\mathbf{g})\end{array}$ \\
\hline 300 & 3500 & 68 \\
\hline
\end{tabular}

Maserasi dilakukan dengan merendam simplisia buah pare menggunakan etanol
96\% selama 5 hari dan dievaporasi menggunakan rotary evaporatoruntuk memperoleh ekstrak yang kental. Berat simplisia buah pare (sampel) sebanyak 300 gram yang direndam dengan pelarut etanol 96\% sejumlah $3500 \mathrm{ml}$, menghasilkan berat ekstrak kental yaitu sebanyak 68 gram.

Tabel 4. Skrining Fitokimia

\begin{tabular}{|c|c|c|c|}
\hline Senyawa & Pereaksi & Hasil Uji & Keterangan \\
\hline \multirow{2}{*}{ Alkaloid } & Dragendrof & Merah bata & + \\
\cline { 2 - 4 } & Mayer & Endapan putih & + \\
\hline Flavonoid & $(\mathrm{HCl}+$ Serbuk $\mathrm{Mg})$ & Kuning & + \\
\hline Saponin & Aquadest & Berbusa & + \\
\hline
\end{tabular}

Skrinning fitokimia merupakan analisis kualitatif terhadap senyawa-senyawa metabolit sekunder. Senyawa-senyawa tersebut dapat diidentifikasi dengan pereaksi-pereaksi yang mampu memberikan ciri khas dari setiap golongan dari metabolit sekunder (Harborne,1987).

Untuk senyawa alkaloid dengan menggunakan 2 peraksi yaitu dragendrof mengahasilkan warna merah bata, sedangkan menggunakan perekasi mayer

\section{Optimasi Basis Gel}

hasil optimasi basis gel dengan 3 variasi konsentrasi HPMC yaitu FI (1\%), F2 $(1,5 \%)$ dan F3 (2\%). Diperoleh basis yang mengahasilkan endapan putih. Diartikan bahwa positif adanya senyawa alkaloid.

Senyawa flavonoid diuji dengan mengunakan pereaksi $\mathrm{HCl} 5$ tetes $+\mathrm{MgCl}$ 5 tetes menghasilkan warna kuning.Dimana parameter adanya senyawa flavonoid apabila terjadi perubahan warna menjadi merah, kuning, atau jingga. Karena perubahan warna yang terjadi adalah kuning maka dinyatakan positif mengandung senyawa flavonoid dalam ekstrak kental buah pare tersebut.

baik dan sesuai dengan persyaratan yaitu pada F3 dengan konsentrasi HPMC 2\% menghasilkan basis gel yang jernih dan viskositasnya baik. 
Tabel 5. Optimasi basis gel

\begin{tabular}{|c|c|c|c|}
\hline \multirow{2}{*}{ Komponen } & \multicolumn{3}{|c|}{ Konsentrasi (\%) } \\
\hline & $\mathbf{F 3}_{\mathrm{A}}$ & $\mathbf{F 3}_{\mathbf{B}}$ & $\mathbf{F 3}_{\mathrm{C}}$ \\
\hline $\begin{array}{c}\text { Ekstrak } \\
\text { buah pare }\end{array}$ & 5 & 7,5 & 10 \\
\hline HPMC & 2 & 2 & 2 \\
\hline Gliserin & 10 & 10 & 10 \\
\hline $\begin{array}{c}\text { Propilengli } \\
\text { kol }\end{array}$ & 5 & 5 & 5 \\
\hline $\begin{array}{c}\text { Dmdm } \\
\text { Hydantoin }\end{array}$ & 1 & 1 & 1 \\
\hline Asam & 0,84 & 0,843 & 0,843 \\
\hline Fosfat & 36 & 6 & 6 \\
\hline Natrium & 0,08 & 0,082 & 0,082 \\
\hline fosfat & 27 & 7 & 7 \\
\hline Aquadest & 100 & 100 & 100 \\
\hline Hasil & $\begin{array}{c}\text { Jern } \\
\text { ih }\end{array}$ & $\begin{array}{c}\text { Jerni } \\
\mathrm{h}\end{array}$ & Jernih \\
\hline
\end{tabular}

\section{Formulasi Sediaan Gel Ekstrak Buah Pare (Momordica charantia L)}

Bentuk sediaan gel lebih baik digunakan pada pengobatan jerawat dibandingkan bentuk sediaan krim karena sediaan gel dengan pelarut yang polar lebih mudah dibersihkan dari permukaan kulit setelah pemakaian dan tidak mengandung minyak yang dapat meningkatkan keparahan jerawat (Sasanto, 2012).

Diformulasikan konsentrasi ekstrak yang berbeda namun dengan konsentrasi basis yang sama. Konsentrasi ekstrak yang

Nur Ain Thomas dkk.... dipilih adalah pada formula $\mathrm{F}_{\mathrm{A}} 5 \%$, formula $\mathrm{F} 3_{\mathrm{B}} 7,5 \%$ dan formula $\mathrm{F} 3_{\mathrm{C}} 10 \%$. Komponen penyusun dalam formula ini yaitu HPMC, gliserin, propilenglikol, dmdm hydantoin, asam fosfat, natrium fosfat, dan aquadest.Berdasarkan pengamatan visual menunjukan hasil yang jernih.

Kemudian dilanjutkan dengan evaluasi kestabilan fisik dan uji efektivitas antibakteri dari gel ekstrak buah pare (Momordica charantia L.) terhadap bakteri penyebab jerawat.

\section{Uji Organoleptis}

Uji Organoleptis bertujuan untuk mengontrol kestabilan sediaan gel secara visual yaitu meliputi wana, bau, dan bentuk dari sediaan.Pengamatan ini dilakukan selama 4 minggu, ditandai dengan $\left(\mathrm{T}_{0}\right)$ hingga minggu ke empat $\left(\mathrm{T}_{3}\right)$ berdasarkan tabel 4.5 Formula $\mathrm{F}_{\mathrm{A}}$, berwarna kuning muda dengan bau khas ekstrak dan tetaphomogen hingga pengamatan pada minggu ke 4. Formula $\mathrm{F} 3_{\mathrm{B}}$ dengan warna gel orange muda dan memiliki bau khas ekstrak dan tetap homogen hingga pengamatan minggu ke empat $\left(T_{3}\right)$, demikian juga dengan formula $\mathrm{F}_{\mathrm{C}} \mathrm{C}$ berwarna orange dengan bau khas ekstrak dan tetap homogen hingga pengamatan minggu ke empat $\left(\mathrm{T}_{3}\right)$. 
Tabel 6. Hasil Uji Organoleptis

\begin{tabular}{|c|c|c|c|c|}
\hline \multirow{3}{*}{ Formula } & $\begin{array}{c}\text { Waktu Pengamatan } \\
(\text { miggu })\end{array}$ & \multicolumn{3}{|c|}{ Organoleptis } \\
\cline { 2 - 5 } & $\mathrm{T}_{0}$ & Warna & Bau & Homogenitas \\
\hline \multirow{4}{*}{$\mathrm{F}_{\mathrm{A}}$} & $\mathrm{T}_{1}$ & Kuning muda & Khas ekstrak & Homogen \\
\cline { 2 - 5 } & $\mathrm{T}_{2}$ & Kuning muda & Khas ekstrak & Homogen \\
\cline { 2 - 5 } & $\mathrm{T}_{3}$ & Kuning muda & Khas ekstrak & Homogen \\
\hline \multirow{4}{*}{$\mathrm{F}_{\mathrm{B}}$} & $\mathrm{T}_{0}$ & Orange muda & Khas ekstrak & Homogen \\
\cline { 2 - 5 } & $\mathrm{T}_{1}$ & Orange muda & Khas ekstrak & Homogen \\
\cline { 2 - 5 } & $\mathrm{T}_{2}$ & Orange muda & Khas ekstrak & Homogen \\
\cline { 2 - 5 } & $\mathrm{T}_{3}$ & Orange muda & Khas ekstrak & Homogen \\
\hline \multirow{3}{*}{$\mathrm{F} 3 \mathrm{C}$} & $\mathrm{T}_{0}$ & Orange & Khas ekstrak & Homogen \\
\cline { 2 - 5 } & $\mathrm{T}_{1}$ & Orange & Khas ekstrak & Homogen \\
\cline { 2 - 5 } & $\mathrm{T}_{2}$ & Orange & Khas ekstrak & Homogen \\
\hline & $\mathrm{T}_{3}$ & Orange & Khas ekstrak & Homogen \\
\hline
\end{tabular}

Daya Sebar

Tabel 7. Hasil uji daya sebar

\begin{tabular}{|c|c|c|c|}
\hline \multirow{2}{*}{$\begin{array}{c}\text { Waktu } \\
\text { pengamatan } \\
\text { (minggu) }\end{array}$} & \multicolumn{3}{|c|}{ Daya Sebar } \\
\cline { 2 - 4 } & $\mathbf{F 3}_{\mathrm{A}}$ & $\mathbf{F 3}_{\mathbf{B}}$ & $\mathbf{F 3}_{\mathbf{C}}$ \\
\hline $\mathrm{T}_{0}$ & $7,5 \mathrm{~cm}$ & $7 \mathrm{~cm}$ & $7 \mathrm{~cm}$ \\
\hline $\mathrm{T}_{1}$ & $7 \mathrm{~cm}$ & $6,7 \mathrm{~cm}$ & $6 \mathrm{~cm}$ \\
\hline $\mathrm{T}_{2}$ & $6,8 \mathrm{~cm}$ & $6,6 \mathrm{~cm}$ & $5,6 \mathrm{~cm}$ \\
\hline $\mathrm{T}_{3}$ & $6,5 \mathrm{~cm}$ & $5,8 \mathrm{~cm}$ & $5 \mathrm{~cm}$ \\
\hline
\end{tabular}

Pengamatan daya sebar dalam penelitian ini dilakukan selama 4 minggu.Pengujian daya sebar sediaan yaitu untuk mengetahui seberapa baik sediaan gel menyebar dipermukaan kulit, karena dapat mempengaruhi absorbsi obat dan kecepatan pelepasan zat aktif ditempat pemakaiannya.

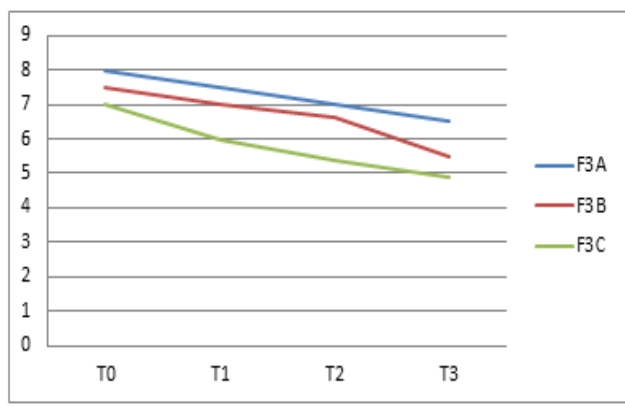

Gambar 1. Kurva daya sebar
Berdasarkan dari hasil kurva tersebut dinyatakan kemampuan menyebar dari sediaan gel yang disimpan mengalami penurunan yang tidak jauh dari masingmasing formula. 


\section{Evaluasi pH}

Evaluasi dilanjutkan dengan uji stabilitas sediaan gel ekstrak buah pare (Momordica charantia L) meliputi evaluasi $\mathrm{pH}$ menggunakan uji freeze thaw. Evaluasi ini dilakukan selama7 siklus dimana untuk setiap siklus dipapar pada suhu $40^{\circ} \mathrm{C}$ selama 48 jam, lalu ditempatkan pada suhu $4^{0} \mathrm{C}$ selama 48 jam.

Pengukuran $\mathrm{pH}$ bertujuan untuk melihat apakah $\mathrm{pH}$ sediaan sesuai dengan $\mathrm{pH}$ kulit, karena gel diaplikasikan secara topikal, maka bila $\mathrm{pH}$ tidak sesuai dengan $\mathrm{pH}$ kulit dapat menyebabkan iritasi pada kulit.Idealnya pH sediaan topikal adalah 4,5-6,5 (Kaur, 2010).

Tabel 8. Hasil Evaluasi pH F3 ${ }_{\mathrm{A}}$ ekstrak $5 \%$

\begin{tabular}{|c|c|l|}
\hline Siklus & $\begin{array}{c}\text { pH } \\
\text { suhu } \\
\text { ruang }\end{array}$ & $\begin{array}{c}\text { pH suhu } \\
\text { freezethaw }\end{array}$ \\
\hline 0 & 6,0 & $6,03 \pm 0115$ \\
\hline 5 & 6,0 & $6,0 \pm 0$ \\
\hline 10 & 6,2 & $6,13 \pm 0,057$ \\
\hline 15 & 6,1 & $6,1 \pm 0$ \\
\hline 20 & 6,1 & $6,16 \pm 0,057$ \\
\hline 25 & 6,2 & 6,16 \\
0,1154 \\
\hline 30 & 6,2 & $6,2 \pm 0$ \\
\hline
\end{tabular}

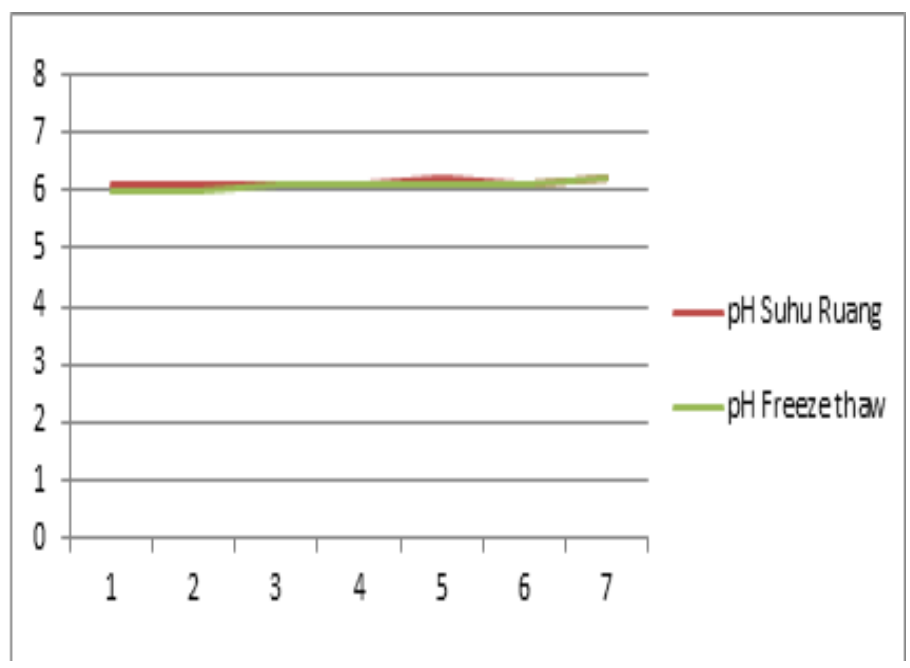

Gambar 2. Kurva evaluasi pH F3 ${ }_{\mathrm{A}}$ ekstrak $5 \%$

Hasil evaluasi stabilitas $\mathrm{pH}$ pada formula dengan penambahan ekstrak $5 \%$ yang disimpan pada suhu ruang dan suhu

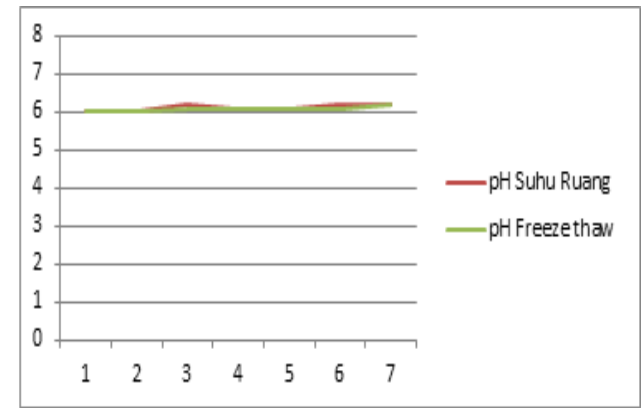

Gambar 3. Kurva evaluasi pH freezethaw pada $\mathrm{T}_{0}$ hingga $\mathrm{T}_{30}$ menghasilkan $\mathrm{pH}$ yang stabil yakni berkisar pada $\mathrm{pH} 6$.

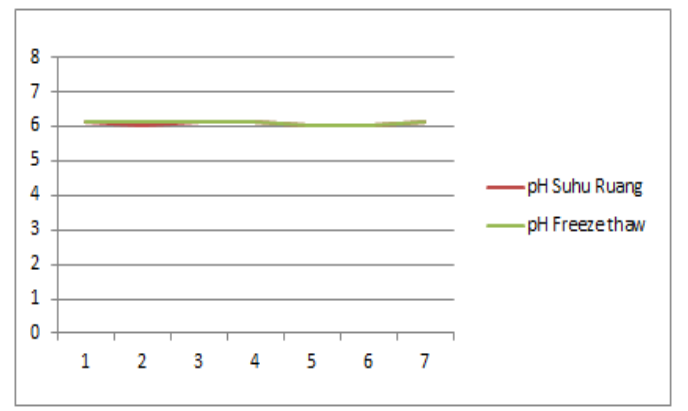

Gambar 4. Kurva evaluasi pH 
Tabel 9. Hasil Evaluasi pH F3 B $_{\text {B }}$ ekstrak 7,5\%

\begin{tabular}{|c|c|c|}
\hline Siklus & $\begin{array}{c}\text { pH suhu } \\
\text { ruang }\end{array}$ & $\begin{array}{l}\text { pH suhu } \\
\text { freezethaw }\end{array}$ \\
\hline 0 & 6,1 & $6,0 \pm 0$ \\
\hline 5 & 6,1 & $\begin{array}{l}6,03 \pm \\
0,11547\end{array}$ \\
\hline 10 & 6,1 & $\begin{array}{l}6,16 \pm \\
0057\end{array}$ \\
\hline 15 & 6,1 & $\begin{array}{l}6,13 \pm \\
0,05773\end{array}$ \\
\hline 20 & 6,2 & $\begin{array}{l}6,16 \pm \\
0,0573\end{array}$ \\
\hline
\end{tabular}

\begin{tabular}{|l|l|l|}
\hline 25 & 6,1 & $\begin{array}{l}6,16 \pm \\
0,11547\end{array}$ \\
\hline 30 & 6,2 & $\begin{array}{l}6,13 \pm \\
0,057\end{array}$ \\
\hline
\end{tabular}

Hasil evaluasi stabilitas $\mathrm{pH}$ pada formula dengan penambahan ekstrak $7,5 \%$ yang disimpan pada suhu ruang dan suhu freezethaw pada $\mathrm{T}_{0}$ hingga $\mathrm{T}_{30}$ menghasilkan $\mathrm{pH}$ yang stabil yakni berkisar pada $\mathrm{pH} 6$.

Tabel 10. Hasil Evaluasi pH F3C ekstrak 10\%

\begin{tabular}{|c|c|l|}
\hline Siklus & $\begin{array}{c}\text { pH suhu } \\
\text { ruang }\end{array}$ & $\begin{array}{c}\text { pH suhu } \\
\text { freezethaw }\end{array}$ \\
\hline 0 & 6,1 & $\begin{array}{l}6,16 \pm \\
0,05773\end{array}$ \\
\hline 5 & 6,0 & $6,1 \pm 0$ \\
\hline 10 & 6,1 & $6,1 \pm 0,1$ \\
\hline 15 & 6,1 & $\begin{array}{l}6,16 \pm \\
0,05773\end{array}$ \\
\hline 20 & 6,0 & $\begin{array}{l}6,06 \pm \\
0,11547\end{array}$ \\
\hline 25 & 6,0 & $\begin{array}{l}6,03 \pm \\
0,05773\end{array}$ \\
\hline 30 & 6,1 & $\begin{array}{l}6,13 \pm \\
0,05773\end{array}$ \\
\hline
\end{tabular}

Hasil evaluasi stabilitas $\mathrm{pH}$ pada formula dengan penambahan ekstrak $10 \%$ yang disimpan pada suhu ruang dan suhu freezethaw pada $\mathrm{T}_{0}$ hingga $\mathrm{T}_{30}$ menghasilkan $\mathrm{pH}$ yang stabil yakni berkisar pada $\mathrm{pH} 6$.

Data yang diperoleh dilanjutkan dengan analisis statistik ANOVA-oneway. Berdasarkan pengujian ANOVA-oneway terlihat bahwa $\mathrm{pH}$ sediaan yang disimpan pada suhu ruang dan suhu freezethaw menunjukan tidak adanya perbedaan yang signifikan sebab memiliki nilai $\mathrm{p}=>0,05$.

\section{Evaluasi Viskositas}

Uji stabilitas sediaan gel ekstrak buah pare (Momordica charantia L) dilanjutkan dengan evaluasi viskositas

menggunakan uji freeze thaw. Tujuan dilakukannya evaluasi freeze thaw ini yaitu untuk mengevaluasi shelf-life dari sediaan tersebut. Evaluasi ini dilakukan 
selama7 siklus dimana untuk setiap siklus dipapar pada suhu $40^{\circ} \mathrm{C}$ selama 48 jam, lalu ditempatkan pada suhu $4^{0} \mathrm{C}$ selama 48 jam.

Tabel 11. Evaluasi Viskositas $\mathrm{F}_{\mathrm{A}}$ ekstrak $5 \%$

\begin{tabular}{|c|c|c|}
\hline Siklus & $\begin{array}{c}\text { Viskositas } \\
\text { pada suhu } \\
\text { ruang }\end{array}$ & $\begin{array}{l}\text { Viskositas } \\
\text { suhu } \\
\text { freezethaw }\end{array}$ \\
\hline 0 & 2096 & $\begin{array}{ll}2865,3 \quad \pm \\
50,80 & \end{array}$ \\
\hline 5 & 2932 & $\begin{array}{ll}3321,3 \quad \pm \\
80,03\end{array}$ \\
\hline 10 & 3056 & $3252 \pm 12$ \\
\hline 15 & 3192 & $\begin{array}{ll}3433,3 \quad \pm \\
23,43 & \end{array}$ \\
\hline 20 & 3024 & $\begin{array}{ll}3117,3 \quad \pm \\
58,28 & \end{array}$ \\
\hline 25 & 3284 & $\begin{array}{ll}3049,3 \quad \pm \\
44,06 & \end{array}$ \\
\hline 30 & 3180 & $\begin{array}{ll}3110,6 \quad \pm \\
22,03 & \end{array}$ \\
\hline
\end{tabular}

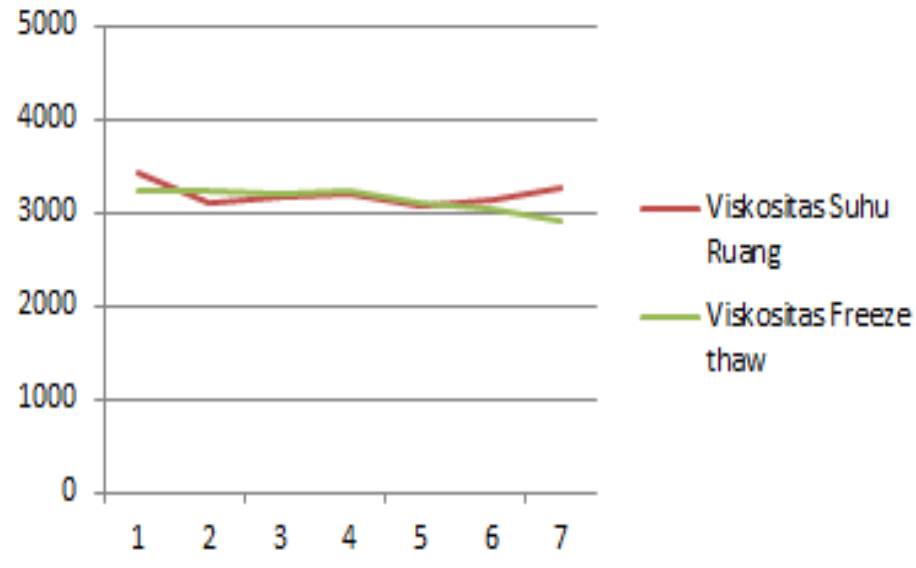

Gambar 5. Kurva viskositas F3A ekstrak 5\%

\section{Evaluasi stabilitas}

$\begin{array}{llll}\text { freezethaw pada } & \mathrm{T}_{0} \text { hingga } & \mathrm{T}_{30}\end{array}$

Hasil stabilitas viskositas pada formula menghasilkan viskositas yang stabil yakni dengan penambahan ekstrak 5\% yang berkisar antara 2000-4000 cps.

disimpan pada suhu ruang dan suhu

Tabel 12. Evaluasi viskositas $\mathrm{F3}_{\mathrm{B}} \mathrm{ekstrak}$ 7,5\%

\begin{tabular}{|c|c|c|}
\hline Siklus & $\begin{array}{c}\text { Viskositas } \\
\text { padasuhu } \\
\text { ruang }\end{array}$ & $\begin{array}{l}\text { Viskositas } \\
\text { suhu } \\
\text { freezethaw }\end{array}$ \\
\hline 0 & 3440 & $\begin{array}{ll}3220 & \pm \\
48,49 & \end{array}$ \\
\hline 5 & 3104 & $\begin{array}{ll}3230,6 & \pm \\
71,14 & \end{array}$ \\
\hline
\end{tabular}

Nur Ain Thomas dkk.... 


\begin{tabular}{|c|c|c|}
\hline 10 & 3180 & $\begin{array}{ll}3186,6 \quad \pm \\
64,66\end{array}$ \\
\hline 15 & 3192 & $\begin{array}{ll}3226,6 \quad \pm \\
39,25 & \end{array}$ \\
\hline 20 & 3084 & $\begin{array}{ll}3108 & \pm \\
80,29 & \end{array}$ \\
\hline 25 & 3128 & $\begin{array}{ll}3046,6 \quad \pm \\
43,14\end{array}$ \\
\hline 30 & 3272 & $\begin{array}{ll}2909,3 \quad \pm \\
44,60 & \end{array}$ \\
\hline
\end{tabular}

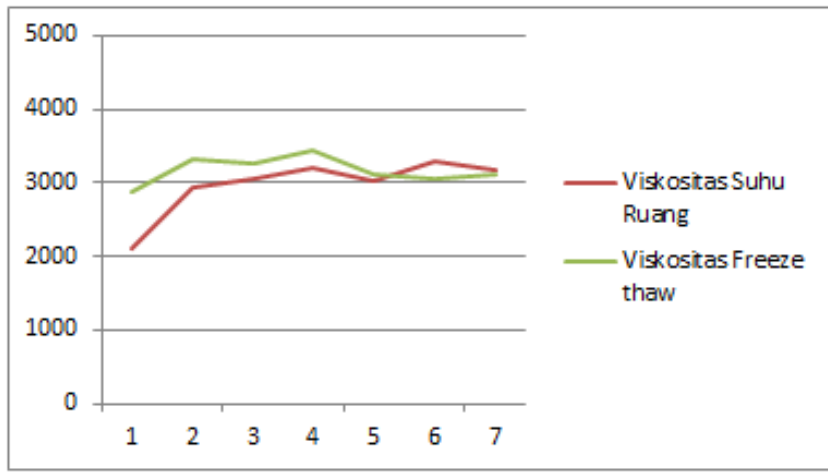

Gambar 6. Kurva stabilitas viskositas F3B ekstrak7,5\%

Hasil evaluasi stabilitas viskositas pada formula dengan penambahan ekstrak 7,5\% yang disimpan pada suhu ruang dan suhu freezethaw pada $\mathrm{T}_{0}$ hingga $\mathrm{T}_{30}$ menghasilkan viskositas yang stabil yakni berkisar antara 2000-4000 cps.

Tabel 13. Evaluasi viskositas F $3_{C}$ ekstrak $10 \%$

\begin{tabular}{|c|c|c|}
\hline Siklus & $\begin{array}{c}\text { Viskositas } \\
\text { pada suhu } \\
\text { ruang }\end{array}$ & $\begin{array}{c}\text { Viskositas } \\
\text { suhu } \\
\text { freezethaw }\end{array}$ \\
\hline 0 & 3032 & $3036 \pm 22,27$ \\
\hline 5 & 3080 & $3276 \pm 46,13$ \\
\hline 10 & 3168 & $3284 \pm 17,43$ \\
\hline 15 & 3200 & $3348 \pm 31,72$ \\
\hline 20 & 3284 & $3440 \pm 21,16$ \\
\hline 25 & 3704 & $3596 \pm 102,0$ \\
\hline 30 & 3256 & $3260 \pm 45,43$ \\
\hline
\end{tabular}

Hasil evaluasi stabilitas viskositas

pada formula dengan penambahan ekstrak

$10 \%$ yang disimpan pada suhu ruang dan suhu freezethaw pada $\mathrm{T}_{0}$ hingga $\mathrm{T}_{30}$ menghasilkan viskositas yang stabil yakni berkisar antara 2000-4000 cps.

Data yang diperoleh dilanjutkan dengan analisis statistik ANOVA-oneway. Berdasarkan pengujian ANOVA-oneway terlihat bahwa viskositas sediaan yang disimpan pada suhu ruang dan suhu freezethaw menunjukan tidak adanya perbedaan yang signifikan sebab memiliki nilai $\mathrm{p}=>0,05$. Suatu data dikatakan signifikan apabila nilai $\mathrm{p}=<0,05$. 


\section{KESIMPULAN}

Berdasarkan hasil penelitian yang telah dilakukan, maka dapat disimpulkan sebagai berikut:

1. Esktrak buah pare (Momordica charantia L) dapat diformulasikan sebagai gel antijerawat.

2. Sediaan gel ekstrak buah pare (Momordica charantia L) pada konsentrasi $10 \%$ mempunyai daya hambat $10 \mathrm{~mm}$ terhadap bakteri Staphylococcus epidermidis dan 7,1 $\mathrm{mm} \quad$ terhadap bakteri Propionibacterium acnes yang termasuk dalam kategori sedang

\section{SARAN}

Perlu dilakukan penelitian lebih lanjut dengan menggunakan formulasi gel yang lebih tepat serta meningkatkan konsentrasi dari ekstrak yang lebih tinggi agar dapat menghasilkan daya hambat lebih besar dan tergolong kategori kuat terhadap bakteri uji

\section{DAFTAR PUSTAKA}

Direktorat Jendral Pengawasan Obat dan Makanan RI. 1995.Farmakope
Indonesia, jilid IV. Jakarta: Departemen Kesehatan Republik Indonesia

Djajadisastra, J., Munim, A dan Dessy., N. P. 2009. Formulasi gel topical dari ekstrak Nerii folium dalam sediaan anti jerawat. Jurnal Farmasi Indonesia $4: 4$

Mertaniasih, N. M., Mudihardi, E., Eko B., Wiqoyah, N., dan Debora, K. 1996.Kepekaan Mikroba dari Acne Vulgaris Terhadap Beberapa Antibiotika. Media IDI

Sasanti, T.J., Wibowo, MS., Fidrianny,I dan Caroline,S. 2012. Formulasi Gel Ekstrak Air Teh Hijau dan Penentuan Aktivitas Antibakterinya Terhadap Propionibacterium Acnes. Bandung: ITB

Septiani, S.N., Wathoni, dan S.R. Mita. 2011. Formulasi Sediaan Masker Gel Antioksidan dari Ekstrak etanol Biji Melinjo (Gnetum gnemon Linn). Bandung: UNPAD

Wasitaatmadja, S.M. 1993.Penuntun Ilmu Kosmetik Medik. Jakarta: UI Press 